\title{
Conversation between Child and Adult as Educational Experience
}

\author{
Eugenia Rostańska*
}

\begin{abstract}
Conversation is a specific component of communication activity. Its peculiar dimension is visible in educational situations. Its main component is the relation between a child and an adult. Key words: conversation, child, communication.
\end{abstract}

In pedagogical studies, conversation is rarely treated autonomously. Most frequently, it is subordinate to more general communication components such as: dialog, interaction and discourse (Rostańska, 2010). It is sometimes analyzed and employed as an efficient component of pedagogical activities upbringing, education or as a form of verbal activity of pupils, constituting the basis for the development of language efficiency and possibility to present natural or unprompted utterances. In scientific research it is also treated as a technique, a manner of data collection, parallel to an interview as a variant of a non-structured dialog method, as natural information exchange and, in a particular way as a mode of research related to the phenomenological and hermeneutic bases.

Conversation, however, as a form or a component of human activity, is not a part of the whole. It is subject to its own organization, imposed by its inherent structural and pragmatic properties. The distinction of its nature is manifested by the following features:

1. Specific organization category - uniqueness, hic at nuc status, undetermined commencement and end, change of roles, language colloquialism, syncretism of forms.

2. Specific communication experience - dyadic nature, presentations and changes in relations, categorization of verbal activity in language behaviors, strategies of kindness, assumed communication styles and preferences.

3. Specific functioning of conversation in educational situations - the child's partner is an adult (teacher, parent, acquaintance or relative), in educational activities such as: explanation, direction, creation of pre-problematic and problematic situations, evaluation, transfer and receipt of information.

Thus, the pedagogue's scientific interest in the issue of child's conversation with an adult means the determination of a separate subject of understanding in terms of philosophy, sociology, psycholinguistics, language prognosis or communication theory, concurrently taking into account the employed theoretical assumptions, scientific procedures and research results. This entails also sharing of a determined exploration field, essential from the pedagogical perspective of application and functioning of conversation within the communication universe. This field is limited by the child's communication experience as a variety of sensations and attempts, the previous experiences, fixed schemes internalized by the child and determining the child's cognitive and communicative activity in conversation with an adult.

In the early school period conversation is the primary form of educational communication, a manner of teacher's communication with a child and of a child with a teacher. It is a means to achieve the upbringing objectives. Conversation is an explanation and transfer of meanings, an attempt to solve problems. In the early school education all children's actions are accompanied mainly by conversation with teachers or adults. Children's behaviors and relations, manners of initiation and ending a conversation, language behaviors as well as communication experience from relations with an adult,

\footnotetext{
* Eugenia Rostańska, Academy of Business in Dąbrowa Górnicza, Dąbrowa Górnicza, Poland; erostanska@wp.pl
} 


\section{Acta Technologica Dubnicae \\ volume 2, 2012, issue 2}

demonstration of oneself and one's world are the essence of conversation. It is a sum of several factors, conditions and, sometimes, a chance. It is also the earlier form of communication experiences of a child.

People learn communication and conversation by themselves. Before a child acquires the ability to read and write as a mode of receiving and messaging the meanings, s/he performs these activities by verbal forms of communication, the basic one being conversation with adults. This process entails the intuition typical for any adult person or child - the ability to recognize conversation and participation in it. The ability to choose conversation as a proper form for the given communication situation or in response to the needs of the communication or participants is also typically intuitive for people.

According to the assumption of the theory of communication, this interaction space must also include the indicators controlling the process of participation in conversation. They also include the use of signals which make the participants perceive the mutual communication as conversation. This is a limitation of the mutual perception of the conversation participants.

The analysis of a child's conversation with an adult is, on the one hand, the study of an independent and structured entity, on the other - elusive, indeterminate, with the nature of a phenomenon the feature of which is uniqueness and the agency is impossible to assess. Commonness of conversation and communicative ethnography (Ostrowska, 2000, p. 22) connected with this issue hinder its qualifications based on strict division into categories. Conversation is a multi-plot thread, continuous supplementation, shaping of communicating persons. The question of the nature of the child's conversation with an adult with certain pedagogical implications must refer to the space of the conversation itself as a form of communication. In this space, in the pedagogical aspect, it is not really the structure that plays the significant role, but the child's experience of the mere communication and relation between a child and an adult. This pertains to the components of the space which are the carriers of educational communication and which have been expressed in the language.

The analysis of communication experience is expected to determine and describe these experiences and communication attempts which result from the child's interaction with an adult in conversation. They constitute an interpretation of the experience, design its use and create the communication habitus.

Therefore, communication experience in the child's conversation with an adult may be determined by the description of sensations and communication attempts in the following analysis categories:

1. Child's interaction with the adult.

2. Child's relation with the adult.

3. Asymmetry of the child's relation with the adult.

4. Strategy of kindness.

5. Effectiveness of the message.

The following categories may be distinguished for the purpose of an analysis of the educational references of the conversation of a child and an adult:

- affective sphere,

- receipt and transfer of meaning,

- explanations,

- direction.

Communication experience in the child's conversation with an adult is very special in educational situations. It arises from the function fulfilled by communication in the education process - learning. Thus, school communication has been the subject of multiple studies and analyses, constituting a pedagogical research field as empirical examples and indication for educational practice. The 


\section{Acta Technologica Dubnicae \\ volume 2, 2012, issue 2}

significance must be attributed to the language features applied by the teachers in didactic communication as well as to the communication patterns of a teacher and a pupil in the auditorium arrangement.

The issue associated with the role of communication in the learning-teaching process has been solved. "School education comes down to the communication of its participants" (Denek, 1998, p. 125). Whereas school "as a place of organized education and upbringing processes, creating characteristic norms of language means selection binding the teacher and pupil in their relations, allows within its framework for qualitatively varied communication behaviors ..." (Wawrzyniak-Beszterda, 2002, p. 37). The education process is sometimes described as a process of symbolic communication expressed in language (Gnitecki, 2001). According to G. Koć-Seniuch (2000), the difference between the pedagogical communication and "other interpersonal communication processes" is expressed in the purposive and intentional influence of teachers on the children and youth in the unconditional acceptance of the child.

"The dialog roles assumed by pupils and teachers in their relations constitute an important socializing factor", as emphasised by R. Wawrzyniak-Beszterda (2002, p. 39) referring to the claims of B. Bernstein, and further on, they result from the fact that the specified nature of social relations influences what, when and how is said. School is treated as a place where we speak and concurrently it is indicated that this speaking is of specific nature. This specificity results from the determined structure of didactic communication, characterized by coerciveness of action, specific course of communication wherein a teacher "makes the language a sublime tool for controlling the children, emphasizing the dominance and authoritarianism" (Gawel-Luty, 2001, p. 231). These indications constitute a result of researches regarding school communication, devoted to the relations between a teacher and a pupil as well as the consequences for communication resulting from the said relation.

The audience is determined by the role of a teacher as a person controlling the communication process. R. Meighan (1993, p. 175) claims that "the prevalent part of speaking in a classroom is constituted by the teacher's utterances ... whereas the main discourse axis is constantly controlled by the teacher or the control over it is rapidly restored by him". This means the so-called limited communication wherein the language interactions may be determined in four movement categories:

1. Constructing movements: aiming at creation and direction of the conversation context and activity during a lesson.

2. Reaction provoking movements - aiming at provoking a reply.

3. Reply movements - directly connected with the constructing movements.

4. Reaction movements - utterances aiming at supplementation, development and evaluation of the previous movement" (Meighan, 1993, p. 175).

These movements correspond to the structure of information in teacher's communication with a pupil comprised by:

1. Maintaining or directing the conversation.

2. Control and supervision over what is said.

3. Confirmation of understanding.

4. Conclusions.

5. Defining.

6. Reacting, precising.

7. Correcting.

8. Determination of features (Janowski, 1989, p. 167-168).

A teacher controls the order of child's utterances and is not controlled by anybody. Thus the difference between - as claimed by A. Janowski (1989) - the "common conversation" and the conversation of a teacher and a child. This results both from the difference of the child - adult and child - teacher 


\section{Acta Technologica Dubnicae \\ volume 2, 2012, issue 2}

relation as well as from the role of the school itself: "school, as a place of organized education and upbringing processes, creating characteristic norms of language means selection binding the teacher and pupil in their relations, allows within its framework for qualitatively varied communication behaviors" (Wawrzyniak-Beszterda, 2002, p. 37). The typical norms of language means selection are constituted, inter alia, by public evaluation.

A teacher not only formulates certain expectations regarding the types of behavior s/he approves, but also during the given lesson, the teacher's questions, tone of voice, gestures, posture, reactions to pupil's replies as well as his/her overall behavior manifest the manners of language use the teacher expects from the pupils. Teacher and pupil create a social context, that is a system of communication and this is what will shape the scope of language strategies applied by the pupils (Rostańska, 1995). Teacher and pupil constitute a variety of the child-adult dyad.

When school communication assumes the form of educational dialogue, it makes the teacher and the pupil two co-acting and cooperating persons, "each of them is open towards the other and ready to speak and listen" (Śnieżyński, 1998, p. 197). However, the difference between everyday communication and communication at a lesson results in the participants of school communication, the pupil and teacher, being unable to select the communication forms freely. The prevalent manner of language use creates - as specified by D. Klaus-Stańska (2000, p. 139; p. 200), a peculiar language climate in everyday classroom contacts. It is characterized by:

1. No trust in the role of spontaneous utterances.

2. Limited legality of colloquial language.

3. Transfer of the written language rules.

4. Asymmetry of linguistic principles.

5. Changes in the communication direction.

6. Depreciation of the pupils' language.

And above all - the conviction that the methods develop the ability to speak not by the speaking situation experience but through listening (Klus-Stańśka, 2000, p. 252).

Educational references in the child's conversation with an adult are represented by a specific affective sphere, explanation, transfer and receipt of meaning and directing. The context of school communication situation results in a child behaving according to the experience it gained within everyday communication. Therefore, the child's choice of communication behaviors at school is a result of what $\mathrm{s} / \mathrm{he}$ has experienced in everyday conversations with adults. Thus, it is also dependant on the degree of commitment of the child in the communication situation, characterised by the adult child dyad as well as on the possibilities provided by the situation.

The child's conversation with an adult possesses a specific structural nature. Its beginning and end depend primarily on the behavior of an adult who reacts to the child's attempt to initiate conversation solely in a situation of an expressed language signal. In such a situation the adult's reaction becomes spontaneous. The adults clearly want to talk about the things a child is telling to them. When they initiate the conversation they somehow emphasize its subject, imposing an official nature onto the entire conversation. A distinct feature is the child's ease of switching between the role of the speaker to the role of the listener and the other way round. Adults do not find this that natural. They prefer to be the speakers, rather than the listeners.

Questions are the privilege of an adult. The adult announces the content of conversation with a question, the child - with a description. Sensations and experiences are shared by the child and the adult however the conversation regarding them is not free from perturbation. A more favorable topic is an object or a phenomenon the observation of which is shared by the child and adult. Adult's closing of the conversation is an unambiguous signal and constitutes a domain of the adults. 
Conversation of a child and an adult possesses its specific place in the field of pedagogical regularities. It is used in the upbringing and educational processes, applied primarily in the early school education and everyday contacts. Knowledge of its structure and rules is an indispensable condition for its application by teachers as a means of communication with a child. Phenomenology and hermeneutics-oriented qualitative research allows to penetrate and to describe this extraordinary phenomenon of child's communication with an adult the best.

\section{References}

DENEK, K.: O nowy ksztatt edukacji [For new shape of education]. Toruń: Wydawnictwo Edukacyjne „Akapit”, 1998.

GAWEŁ-LUTY, E.: Komunikacja szkolna, jako podstawowy warunek socjalizacji ucznia [School communication as the basic condition for pupil's socialization]. In: Procesy komunikacyjne $w$ szkole. Wyznaczniki, tendencje, problemy [Communication processes at school. Indicators, tendencies, problems]. Ed. W. Kojs. Katowice: Wydawnictwo Uniwersytetu Śląskiego, 2001.

GNITECKI, J.: Komunikacja symboliczna w systemach edukacyjnych opartych na metarealistycznych podstawach [Symbolic communication in the educational systems based on materialistic foundations]. In: Procesy komunikacyjne $w$ szkole. Wyznaczniki, tendencje, problemy [Communication processes at school. Indicators, tendencies, problems]. Ed. W. Kojs. Katowice: Wydawnictwo Uniwersytetu Śląskiego, 2001.

JANOWSKI, A.: Uczeń $w$ teatrze życie szkolnego [Pupil in the school life theatre]. Warszawa: Wydawnictwa Szkolne i Pedagogiczne, 1989.

KLUS-STAŃSKA, D.: Konstruowanie wiedzy w szkole [Constructing knowledge at school]. Olsztyn: Wydawnictwo Uniwersytetu Warmińsko-Mazurskiego, 2000.

KOĆ-SNIUCH, G.: Komunikacyjny charakter procesów edukacyjnych [Communicative nature of educational processes]. In: Nauczyciel i uczniowie $w$ dyskursie edukacyjnym [Teacher and pupils in the educational discourse]. Eds. G. Koć-Seniuch, A. Cichocki. Białystok: Trans Humana, 2000.

MEIGHAN, R.: Socjologia edukacji [Sociology of education]. Transl. E.Kiszkurno-Koziej, Z. Knutsen, P. Kwieciński. Toruń: Uniwersytet Mikołaja Kopernika, 1993.

OSTROWSKA, U.: Dialog $w$ pedagogicznym badaniu jakościowym [Dialogue in the pedagogical qualitative examination]. Kraków: Impuls, 2000.

ROSTAŃSKA, E.: Rozmowa w szkole [Discussion at school]. Kraków: Wydawnictwo Edukacyjne, 1995.

ROSTAŃSKA, E.: Dziecko $i$ dorosły $w$ rozmowie. Doświadczanie komunikacji. Odniesienia edukacyjne [Adult and child in conversation. Communication experience. Educational references]. Katowice: Wydawnictwo Uniwersytetu Śląskiego, 2010.

ŚNIEŻYŃSKI, M.: Zarys dydaktyki dialogu [Dialogue didactics outline]. Kraków: Wydawnictwo Naukowe PAT, 1998.

WARZYNIAK-BESZTERDA, R.: Doświadczenia komunikacyjne ucznów w czasie lekcji [Communication experiences of pupils during a lesson]. Kraków: Impuls, 2002. 